\title{
BIOKONVERSI KULIT PISANG RAJA (Musa paradisiaca) DENGAN Rhizopus oligosporus TERHADAP PERUBAHAN KANDUNGAN BAHAN KERING, BAHAN ORGANIK DAN PROTEIN KASAR
}

\author{
Mirsad C. Mokoolang, F. R. Wolayan*, M. R. Imbar, W. L. Toar \\ Fakultas Peternakan Universitas Sam Ratulangi Manado, 95115
}

\begin{abstract}
ABSTRAK
Penelitian ini bertujuan untuk mengetahui perubahan kandungan bahan kering, bahan organik dan protein kasar pada kulit pisang raja (Musa paradisiaca) yang difermentasi dengan Rhizopus oligosporus.Penelitian ini dilakukan selama tiga minggu, menggunakan Rancangan Acak Lengkap (RAL) yang terdiri dari 9 perlakuan dan masing-masing perlakuan diulang 3 kali. Perlakuannya terdiri atas P1 (dosis inokulum $0,2 \%$ dan waktu fermentasi 48 jam), P2 (dosis inokulum 0,4\% dan waktu fermentasi 48 jam), P3 (dosis inokulum $0,6 \%$ dan waktu fermentasi 48 jam), P4 (dosis inokulum $0,2 \%$ dan waktu fermentasi 96 jam), P5 (dosis inokulum 0,4\% dan waktu fermentasi 96 jam), P6 (dosis inokulum $0,6 \%$ dan waktu fermentasi 96 jam), P7 (dosis inokulum $0,2 \%$ dan waktu fermentasi 144 jam), P8 (dosis inokulum $0,4 \%$ dan waktu fermentasi 144 jam) dan P9 (dosis inokulum $0,6 \%$ dan waktu fermentasi 144 jam).Hasil sidik ragam menunjukkan bahwa perlakuan dosis inokulum dan waktu fermentasi memberikan pengaruh yang nyata $(\mathrm{P}<0,05)$ terhadap perubahan kandungan bahan kering, bahan organik dan protein kasar. Berdasarkan hasil penelitian ini dapat disimpulkan bahwa biokonversi kulit pisang raja (Musa paradisiaca) dengan Rhizopus oligosporus dapat meningkatkan persentase perubahan kandungan bahan kering dan protein kasar tetapi terjadi penurunan kandungan bahan organik.
\end{abstract}

*Korespondensi (corresponding author): Email :feny_wolayan@unsrat.ac.id
Penggunaan dosis inokulum $0,4 \%$ dan waktu fermentasi 96 jam (P5) ) dapat meningkatkan persentase perubahan kandungan bahan kering sebesar 6,55\%, menurunkan persentase perubahan kandungan bahan organik sebesar 3,97\% dan meningkatkan persentase perubahan kandungan protein kasar sebesar $60,91 \%$.

Kata Kunci :Biokonversi, Kulit Pisang Raja, Rhizopus oligosporus

\section{ABSTRACT}

BIOCONVERSION OF BANANA PEEL Var. Raja (Musa paradisiaca) WITH Rhizopus oligosporus TO CHANGE OFDRY MATTER CONTENT, ORGANIC MATTER AND CRUDE PROTEIN. This study aims to determine the change of dry matter content, organic matter and crude protein in banana peel var. raja (Musa paradisiaca) fermented with Rhizopus oligosporus. The study was conducted for three weeks, using Completely Randomized Design (RAL) consisting of 9 treatments and each treatment was repeated 3 times. The treatment consisted of P1 (inoculum dose $0.2 \%$ and 48 hours fermentation time), P2 (inoculum dose $0.4 \%$ and 48 hours fermentation time), P3 (inoculum dose $0.6 \%$ and 48 hours fermentation time), P4 (inoculum dose $0.2 \%$ fermentation 96 hours), P5 (inoculum dose $0.4 \%$ and 96 hours fermentation time), P6 (inoculum dose $0.6 \%$ and 96 hours fermentation time), P7 (inoculum dose $0.2 \%$ and fermentation 
time 144 hours), P8 (inoculum dose $0.4 \%$ and fermentation time 144 hours) and P9 (inoculum dose $0.6 \%$ and fermentation time 144 hours). The results of variance indicated that the treatment of dose inoculum and fermentation time had a significant effect $(\mathrm{P}<0.05)$ on dry matter content, organic matter and crude protein. Based on the result of this research, it can be concluded that banana peel var. raja bioconversion (Musa paradisiaca) with Rhizopus oligosporus can increase percentage change of dry matter and crude protein but there is decrease of organic matter content. The use of $0.4 \%$ inoculum dosage and 96 hours of fermentation time (P5) could increase the percentage change of dry matter content by $6.55 \%$, decrease the percentage change of organic matter content by $3.97 \%$ and increase the percentage change of crude protein content by $60,91 \%$.

Keywords: Bioconversion, Banana Peel var. Raja, Rhizopus oligosporus

\section{PENDAHULUAN}

Bahan pakan alternatif dapat menekan harga pakan dengan memanfaatkan limbah pertanian.Salah satu limbah pertanian yang dapat menjadi bahan pakan alternatif yaitu kulit pisang raja.Kulit pisang raja (Musa paradisiaca) merupakan bahan buangan (limbah buah pisang) yang cukup banyak jumlahnya atau ketersediaanya cukup banyak.Kulit pisang segar mengandung protein kasar $7.64 \%$, lemak $3,02 \%$ dan abu $9.60 \%$ serta serat kasar yaitu 17,30\% (Laboratorium kimia dan makanan ternak unpad, 2017).Terbatasnya pemanfaatan kulit pisang raja sebagai bahan pakan karena kandungan protein kasarnya rendah dan tingginya kandungan serat kasar. Sehingga perlu adanya upaya perbaikan kandungan nutrien, yaitu dengan proses fermentasi.

Fermentasi merupakan salah satu upaya untuk meningkatkan nilai gizi bahan berkualitas rendah dengan bantuan mikroorganisme, salah satunya dengan kapangRhizopus oligosporus.Rhizopus oligosporusmerupakan kapang dari filum Zygomycota yang banyak menghasilkan enzim protease.Kapang ini dapat merombak senyawa kompleks protein menjadi senyawa-senyawa yang lebih sederhana dan dapat menghasilkan enzim amilase, lipase dan pektinase.

Fermentasi kulit pisang kepok oleh Rhyzopus oligosporus dengan dosis 3 gram untuk setiap $\mathrm{kg}$ kulit pisangselama 48 jamdapat meningkatkan persentase kandungan protein kasar dari 3,63\% menjadi 22,15\% (Koni, 2009 dalam Koni 2013).Berdasarkan uraian di atas maka dilakukan penelitian untuk mengetahui perubahan kandungan bahan kering, bahan organik, dan protein kasar pada kulit pisang raja yang difermentasi dengan Rhizopus oligosporus melalui analisis proksimat.

\section{MATERI DAN METODE PENELITIAN}

Penelitian ini telah dilaksanakan di Fakultas Peternakan Universitas Sam 
Ratulangi Manado, pada tanggal 12 Februari 2017 sampai tanggal 3 Maret 2017, dengan menggunakan Rancangan Acak Lengkap (RAL) terdiri dari 9 perlakuan dan masingmasing perlakuan di ulang 3 kali (Steel dan Torrie, 1995).Perlakuannya terdiri atas : P1 (dosis inokulum $0,2 \%$ dan waktu fermentasi 48 jam), P2 (dosis inokulum 0,4\% dan waktu fermentasi 48 jam), P3 (dosis inokulum $0,6 \%$ dan waktu fermentasi 48 jam), P4 (dosis inokulum 0,2\% dan waktu fermentasi 96 jam), P5 (dosis inokulum 0,4\% dan waktu fermentasi 96 jam), P6 (dosis inokulum 0,6\% dan waktu fermentasi 96 jam), P7 (dosis inokulum 0,2\% dan waktu fermentasi 144 jam), P8 (dosis inokulum 0,4\% dan waktu fermentasi 144 jam) dan P9 (dosis inokulum 0,6\% dan waktu fermentasi 144 jam). Alat dan bahan yang digunakan dalam penelitian ini yaitu: kompor gas, pisau, kukusan, kantungplastik, bakipalstik, timbangan, sarung tangan, alkohol, termometer ruang, blender, oven pengering, kulit pisang raja diperoleh dari Limbah penggorengan pisang di kota Manado dan Ragi tempe (Rizhopus oligosporus) diperoleh dari home industry tempe di kota Manado.Variabel yang di ukur dalam penelitian ini adalah perubahan kandungan bahan kering, bahan organik dan protein kasar.

\section{Pembuatan inokulum ragi tempe (Rizhopus oligosporus)}

Sebanyak 320 gram Ragi tempe (yang diperolehdarihome industry) diinokulasikan dengan 80 gram kulit pisang raja yang sudah ditepungkan. Kemudian disimpan dalam toples yang sudah disterilisasi supaya tidak terkontaminasi dengan mikroorganisme lain.

\section{Prosedur fermentasi kulit pisang raja (Musa paradisiaca)}

Kulit pisang yang telah dipilih, dicuci dengan air bersih kemudian dipotong $\pm 2 \mathrm{~cm}$. kulit pisang yang telah dipotong dimasukkan dalam plastik, kemudian dimasukkan dalam alat pengukus setelah air mendidih selama 15 menit.pengukusan berfungsi untuk mematikan mikroba pathogen pada kulit pisang.tebarkan kulit pisang raja yang telah dikukus diatas nampan dan diangin-anginkan, setelah dingin dimasukan dalam kantong plastik. Inokulasikan dengan inokulum yang telah dibuat sesuai dengan perlakuan yaitu( $0,2 \%$, 0,4\% dan 0,6\%) dari 400 gram kulit pisang raja. campur kulit pisang dengan inokulum sesuai dengan perlakuan sampai homogen, masing-masing dimasukan dalam kantong plastik yang sudah dilubangi ke 2 sisinya untuk mendapatkan kondisi aerob. Inkubasi dalam suhu ruang $\left(25-28^{\circ} \mathrm{C}\right)$ selama 48 jam , 96 jam dan 144 jam, masing-masing perlakuan diulang sebanyak 3 kali. kemudian keringkan semua perlakuan dengan menggunakan oven padasuhu $60{ }^{\circ} \mathrm{C}$ 
selama 3 hari( sampai diperoleh berat konstan). selanjutnya dilakukan pengujian kandunga nnutrisi produk fermentasi melalui analisis proksimat.

\section{HASIL DAN PEMBAHASAN}

\section{Pengaruh Perlakuan Terhadap Perubahan Kandungan Bahan Kering}

Hasil pengamatan dan perhitungan persentase perubahan kandungan bahan kering dari masaing-masing perlakuan yang diberikan selama penelitian dapat dilihat pada Tabel 1. Data hasil penelitian menunjukkan persentase perubahan kandungan bahan kering kulit pisang raja (Musa paradisiaca) yang difermentasi berkisar antara 3,05\% - 9,08\%. Persentase perubahan kandungan bahan kering tertinggi diperoleh pada perlakuan P9 (dosis inokulum $0,6 \%$ dan waktu fermentasi 144 jam) yaitu 9,08\% dan persentase perubahan kandungan bahan kering terendah diperoleh pada perlakuan P1 (dosis inokulum 0,2\% dan waktu fermentasi 48 jam) yaitu 3,05\%. Hasil analisis ragam menunjukkan bahwa fermentasi kulit pisang raja dengan Rhizopus oligosporus memberi pengaruh berbeda nyata $\quad(\mathrm{P}<0,05) \quad$ terhadap perubahan kandungan bahan kering. Perubahan kandungan bahan kering pada kulit pisang raja terjadi karena adanya aktivitas kapang (Rhizopus oligosporus). Semakin meningkat dosis inokulum dan lama fermentasi, maka semakin besar pula persentase perubahan kandungan bahan kering produk fermentasi. Selanjutnya untuk melihat perbedaan pengaruh antar perlakuan dilakukan uji BNJ.

Hasil uji lanjut BNJ menunjukkan P9 (dosis inokulum 0,6\% dan waktu fermentasi 144 jam) yaitu $9,08 \%$ berbeda tidak nyata $(\mathrm{P}>0,05)$ dengan $\mathrm{P} 8$ (dosis inokulum $0,4 \%$ dan waktu fermentasi 144 jam) yaitu $8.40 \%$ tetapi berbeda nyata ( $\mathrm{P}<0,05)$ lebih tinggi dengan P6 (dosis inokulum 0,6\% dan waktu fermentasi 96 jam) yaitu $8.23 \%$, P5 (dosis inokulum $0,4 \%$ dan waktu fermentasi 96 jam) yaitu 6,55\%, P7 (dosis inokulum 0,2\% dan waktu fermentasi 144 jam) yaitu 6,16\%, P4 (dosis inokulum 0,2\% dan waktu fermentasi 96 jam) yaitu 5,02\%, P3 (dosis inokulum 0,6\% dan waktu fermentasi 48 jam) yaitu 4,99\%, P2 (dosis inokulum 0,4\% dan waktu fermentasi 48 jam) yaitu $3,46 \%$ dan P1 (dosis inokulum $0,2 \%$ dan waktu fermentasi 48 jam) yaitu 3,05\%. Perbedaaan pengaruh antar perlakuan disebabkan oleh perbedaan dosis inokulum dan waktu fermentasi. Pada perlakuan dengan dosis inokulum $0.6 \%$ selama 144 jam (P9) menghasilkan nilai tertinggi persentase perubahan kandungan bahan kering yaitu 9,08\%, diikuti dengan perlakuan dosis inokulum $0,4 \%$ selama 144 jam (P8) yaitu 8,40\% dan perlakuan dosis inokulum 0,6\% selama 96 jam (P6) yatu $8,23 \%$. Penelitian ini sejalan dengan Abun (2003) yang menyatakan bahwa semakin 
Tabel 1. Persentase Perubahan Kandungan Bahan Kering Kulit Pisang Raja (Musa paradisiaca) yang difermentasi dengan Rhizopus oligosporus

\begin{tabular}{|c|c|c|c|c|c|}
\hline \multirow{2}{*}{ Perlakuan } & \multicolumn{3}{|c|}{ Ulangan } & \multirow[b]{2}{*}{ Total } & \multirow[b]{2}{*}{ Rataan } \\
\hline & 1 & 2 & 3 & & \\
\hline $\mathrm{P} 1$ & 2,88 & 2,73 & 3,54 & 9,15 & $3,05^{\mathrm{e}}$ \\
\hline $\mathrm{P} 2$ & 2,88 & 3,81 & 3,68 & 10,37 & $3,46^{\mathrm{e}}$ \\
\hline P3 & 5,17 & 4,82 & 4,99 & 14,98 & $4,99^{\mathrm{d}}$ \\
\hline P4 & 4,80 & 5,03 & 5,22 & 15,05 & $5,02^{d}$ \\
\hline P5 & 7,08 & 5,66 & 6,90 & 19,64 & $6,55^{\mathrm{c}}$ \\
\hline P6 & 8,30 & 7,68 & 8,71 & 24,69 & $8,23^{b}$ \\
\hline P7 & 6,11 & 5,99 & 6,39 & 18,49 & $6,16^{\mathrm{c}}$ \\
\hline P8 & 8,33 & 8,26 & 8,61 & 25,20 & $8,40^{\mathrm{ab}}$ \\
\hline P9 & 9,70 & 8,58 & 8,97 & 27,25 & $9,08^{\mathrm{a}}$ \\
\hline
\end{tabular}

Meningkatnya dosis inokulum yang diikuti oleh lamanya waktu fermentasi menyebabkan terjadinya perubahan terhadap kandungan bahan kering produk fermentasi. Waktu fermentasi yang lebih lama menyebabkan pertumbuhan kapang akan semakin baik, merata dan kompak. Menurut Kasmiran (2011), bahwa semakin banyak kapang yang tumbuh maka semakin tinggi aktivitas kapang menggunakan zat makanan yang ada pada media kemudian dirombak menjadi energi. Meningkatnya persentase perubahan kandungan bahan kering pada penelitian ini sesuai dengan pendapatWinarno, (1980) bahwa pada saat fermentasi sebagian air akan tertinggal dalam produk dan sebagian lagi akan keluar dari produk. Air yang keluar dari produk yang akan menyebabkan bahan kering meningkat. penelitian ini sejalan dengan Abun (2003) menyatakan bahwa peningkatan dosis inokulum dan waktu fermentasi pada ampas umbi garut dapat meningkatkan kandungan bahan kering produk fermentasi.

\section{Pengaruh Perlakuan Terhadap Perubahan Kandungan Bahan Organik}

Hasil pengamatan dan perhitungan persentase perubahan kandungan bahan organik dari masaing-masing perlakuan yang diberikan selama penelitian dapat dilihat pada Tabel 2. Data hasil penelitian menunjukkan persentase perubahan kandungan bahan organik kulit pisang raja (Musa paradisiaca) yang difermentasi dengan Rhizopus oligosporus berkisar antara $0,87 \%-4,54 \%$. Persentase perubahan kandungan bahan organik tertinggi diperoleh pada perlakuan P8 dosis inokulum $0,4 \%$ dan waktu fermentasi 144 jam yaitu 4,54\%. Sementara persentase perubahan kandungan bahan organik terendah diperoleh pada perlakuan P1 dosis inokulum $0,2 \%$ dan waktu fermentasi 48 
jam yaitu $0,87 \%$. Hasil analisis ragam menunjukkan bahwa fermentasi kulit pisang raja dengan Rhizopus oligosporus memberi pengaruh berbeda nyata $(\mathrm{P}<$ 0,05) terhadap perubahan kandungan bahan organik. Persentase perubahan kandungan bahan organik pada kulit pisang raja terjadi karena adanya aktivitas kapang (Rhizopus oligosporus).Semakin meningkat dosis inokulum dan lama fermentasi, maka semakin besar pula persentase penurunan kandungan bahan kering produk fermentasi.Selanjutnya untuk melihat perbedaan pengaruh antar perlakuan dilakukan uji BNJ.

Hasil uji lanjut BNJ menunjukan P8 (dosis inokulum 0,4\% dan waktu fermentasi 144 jam) yaitu $4,54 \%$ berbeda tidak nyata $(\mathrm{P}>0,05)$ dengan $\mathrm{P} 9$ (dosis inokulum 0,6\% dan waktu fermentasi 144 jam) yaitu 4,27\% dan P5 (dosis inokulum 0,4\% dan waktu fermentasi 96 jam) yaitu $3,97 \%$, tetapi berbeda nyata $(\mathrm{P}<0,05)$ lebih tinggi dengan P6 (dosis inokulum 0,6\% dan waktu fermentasi 96 jam) yaitu 3,00\%, P7 (dosis inokulum 0,2\% dan waktu fermentasi 144 jam) yaitu 1,96\%, P4 (dosis inokulum $0,2 \%$ dan waktu fermentasi 144 jam) yaitu 1,72\%, P2 (dosis inokulum $0,4 \%$ dan waktu fermentasi 48 jam) yaitu 1,34\%, P3 (dosis inokulum $0,6 \%$ dan waktu fermentasi 48 jam) yaitu 1,29\% dan P1 (dosis inokulum
0,2\% dan waktu fermentasi 48 jam) yaitu $0,87 \%$.Perbedaaan pengaruh antar perlakuan disebabkan oleh perbedaan dosis inokulum dan waktu fermentasi. Pada perlakuan dengan dosis inukulum 0,4\% selama 144 jam (P8) menghasilkan nilai tertinggi persentase perubahan kandungan bahan organik yaitu 4,54\%, diikuti dengan dosis inokulum $0,6 \%$ selama 144 jam (P9) yaitu 4,27\% dan dosis inokulum 0,4\% selama 96 jam (P5) yaitu $3,97 \%$. Semakin meningkatnya dosis inokulum yang dikuti lamanya waktu fermentasi dapat menyebabkan terjadinya perubahan kandungan bahan organik, karena nutrien yang tersedia pada bahan telah dirombak dan dimanfaatkan oleh kapang (Rhizopus oligosporus). Dengan adanya kapang ini maka akan terjadi pemecahan komponen-komponen dari kulit pisang raja. Penelitian ini sejalan dengan Mirzah dan Muis, (2015) yang menyatakan dosis inokulum yang tepat akan memberikan kesempatan pada kapang agar tumbuh dan berkembang dengan cepat, semakin banyak inokulum yang dipakai maka semakin cepat pertumbuhannya, sehingga semakin banyak pula substrat yang dirombak seperti bahan organik. Menurut Kasmiran, (2011) kapang yang tumbuh pada media akan semakin aktif melakukan perombakan karbohidrat dan protein yang 
Tabel 2. Persentase Perubahan Kandungan Bahan Organik Kulit Pisang Raja(Musa paradisiaca) yang difermentasi dengan Rhizopus oligosporus

\begin{tabular}{|c|c|c|c|c|c|}
\hline \multirow{2}{*}{ Perlakuan } & \multicolumn{3}{|c|}{ Ulangan } & \multirow[b]{2}{*}{ Total } & \multirow[b]{2}{*}{ Rataan } \\
\hline & 1 & 2 & 3 & & \\
\hline $\mathrm{P} 1$ & 1,01 & 0,92 & 0,69 & 2,62 & $0,87^{\mathrm{d}}$ \\
\hline $\mathrm{P} 2$ & 1,02 & 1,44 & 1,56 & 4,02 & $1,34^{\mathrm{cd}}$ \\
\hline P3 & 1,31 & 1,56 & 1,00 & 3,87 & $1,29^{\mathrm{cd}}$ \\
\hline P4 & 2,16 & 1,43 & 1,57 & 5,16 & $1,72^{\mathrm{c}}$ \\
\hline P5 & 4,26 & 3,65 & 3,99 & 11,90 & $3,97^{\mathrm{a}}$ \\
\hline P6 & 2,92 & 3,54 & 2,54 & 9,00 & $3,00^{\mathrm{b}}$ \\
\hline P7 & 1,06 & 2,39 & 2,44 & 5,89 & $1,96^{\mathrm{c}}$ \\
\hline P8 & 5,13 & 4,85 & 3,64 & 13,62 & $4,54^{\mathrm{a}}$ \\
\hline P9 & 4,38 & 3,67 & 4,75 & 12,80 & $4,27^{\mathrm{a}}$ \\
\hline
\end{tabular}

Ket :Superscript yang tidak sama pada kolom rataan menunjukkan pengaruh perlakuan yangn berbeda nyata $(P<0,05)$

merupakan bagian dari bahan organik sehingga kandungan bahan organik akan mengalami penurunan. Matsir dan Djunaidi (2006) melaporkan bahwa fermentasi dapat menurunkan kandungan bahan organik limbah garut dan limbah udang.

\section{Pengaruh Perlakauan Terhadap Perubahan Kandungan Protein Kasar}

Hasil pengamatan dan perhitungan persentase perubahan kandungan protein kasar dari masaing-masing perlakuan yang diberikan selama penelitian dapat dilihat pada Tabel 3. Data hasil penelitian menunjukan persentase perubahan kandungan protein kasar kulit pisang raja yang difermentasi berkisar antara 35,60\% - 64,53\%. Persentase perubahan kandungan protein kasar tertinggi diperoleh pada perlakuan P9 (dosis inokulum 0,6\% dan waktu fermentasi 144 jam). Sedangkan persentase perubahan kandungan protein kasar terendah diperoleh pada perlakuan P1 (dosis inokulum $0,2 \%$ dan waktu fermentasi 48 jam). Hasil analisis ragam menunjukan bahwa fermentasi kulit pisang raja dengan Rhizopus oligosporus memberi pengaruh berbeda nyata $(\mathrm{P}<0,05) \quad$ terhadap perubahan kandungan protein kasar. Persentase perubahan kandungan protein kasar pada kulit pisang raja terjadi karena adanya aktivitas kapang (Rhizopus oligosporus).Semakin meningkat dosis inokulum dan lama fermentasi, maka semakin besar pula persentase perubahan kandungan protein kasar produk fermentasi.Selanjutnya untuk melihat perbedaan pengaruh antar perlakuan dilakukan uji BNJ.

Hasil uji lanjut BNJ menunjukkan P9 (dosis inokulum 0.6\% selama 144 jam) yaitu $64,53 \%$ berbeda tidak nyata $(\mathrm{P}>0,05)$ dengan P6 (dosis inokulum 0.6\% dan waktu fermentasi 96 jam) yaitu $63.83 \%$, 
Tabel 3.Persentase Perubahan Kandungan Protein Kasar Pisang Raja (Musa paradisiaca) yang difermentasi dengan Rhizopus oligosporus

\begin{tabular}{|c|c|c|c|c|c|}
\hline \multirow{2}{*}{ Perlakuan } & \multicolumn{3}{|c|}{ Ulangan } & \multirow[b]{2}{*}{ Total } & \multirow[b]{2}{*}{ Rataan } \\
\hline & 1 & 2 & 3 & & \\
\hline P1 & 29,58 & 40,31 & 36,91 & 106,81 & $35,60^{c}$ \\
\hline $\mathrm{P} 2$ & 40,97 & 41,10 & 44,76 & 126,83 & $42,28^{\mathrm{b}}$ \\
\hline $\mathrm{P} 3$ & 45,16 & 44,24 & 43,85 & 133,25 & $44,42^{\mathrm{b}}$ \\
\hline $\mathrm{P} 4$ & 46,86 & 49,74 & 44,63 & 141,23 & $47,08^{b}$ \\
\hline P5 & 57,20 & 60,86 & 64,66 & 182,72 & $60,91^{\mathrm{a}}$ \\
\hline P6 & 59,95 & 64,40 & 67,15 & 191,50 & $63,83^{\mathrm{a}}$ \\
\hline P7 & 59,55 & 59,95 & 56,94 & 176,44 & $58,81^{\mathrm{a}}$ \\
\hline P8 & 63,48 & 56,94 & 69,90 & 190,32 & $63,44^{\mathrm{a}}$ \\
\hline P9 & 65,71 & 60,73 & 67,15 & 193,59 & $64,53^{\mathrm{a}}$ \\
\hline
\end{tabular}

Ket :Superscript yang tidak sama pada kolom rataan signifikasi menunjukkan pengaruh perlakuan yang berbeda nyata $(P<0,05)$

P8 (dosis inokulum $0,4 \%$ dan waktu fermentasi 144 jam) yaitu 63.44\%, P5 (dosis inokulum $0,4 \%$ dan waktu fermentasi 96 jam) yaitu 60,91\% dan P7 (dosis inokulum $\quad 0,2 \%$ dan waktufermentasi 144 jam) yaitu 58,81\%, tetapi berbeda nyata $(\mathrm{P}<0.05)$ lebih tinggi dengan P4 (dosis inokulum 0,2\% dan waktu fermentasi 96 jam) yaitu 47,08, P3 (dosis inokulum $0,6 \%$ dan waktu fermentasi 48 jam) yaitu 44,42\%, P2 (dosis inokulum $0,4 \%$ dan waktu fermentasi 48 jam) yaitu 42,28\% dan P1 (dosis inokulum $0,2 \%$ dan waktu fermentasi 48 jam) 35,60\%.

Persentase perubahan kandungan protein kasar kulit pisang raja (Musa paradisiaca) setelah fermentasi dipengaruhi oleh dosis inokulum dan lama fermentasi. Pada perlakuan dengan dosis inokulum 0,6\% selama 144 jam (P9) menghasilkan nilai tertinggi yaitu $64,53 \%$, diikuti dengan perlakuan dosis inokulum 0,6\% selama 96 jam (P6) yaitu 63,83\% dan perlakuan dosis inokulum $0,2 \%$ selama 144 jam (P8) yaitu 63,44\%. Adanya kemampuan kapang Rhizopus oligosporusdalam menghasilkan enzim protease menyebabkan protein kasar padakulit pisang raja meningkat.Fardiaz, (1992) menyatakan bahwa Rhizopus oligosporus merupakan kapang yang dapat menghasilkan enzim protease dan aktivitas proteolitik yang tinggi. Waktu fermentasi berhubungan dengan aktivitas enzim, semakin lama waktu fermentasi membuat populasi kapang ini semakin meningkat. Penelitian ini sejalan dengan Yohanista dkk, (2014) yang menyatakan bahwa kandungan protein kasar produk fermentasi sangat dipengaruhi oleh waktu inkubasi selama proses fermentasi, sebab 
berhubungan dengan aktivitas enzim yang akan meningkat seiring bertambahnya waktu inkubasi. Demikian jugaSetiyatwan, (2007); Mirzah dan Muis (2015), menyatakan bahwa dalam proses fermentasi ada beberapa hal yang harus diperhatikan, diantaranya dosis inokulum dan lama fermentasi. Dosis inokulum yang tepat akan memberikan kesempatan pada mikroba agar tumbuh dan berkembang dengan cepat, dimana semakin banyak inokulum yang digunakan maka waktu yang dibutuhkan untuk meningkatkan kandungan protein kasar semakin singkat.

Kenaikan persentase kandungan protein kasar kulit pisang yang difermentasi juga pernah dilaporkan oleh Koni(2009) dalam Koni (2013) bahwa protein kasar kulit pisang kepok yang difermentasi dengan Rhizopus oligosporus mengalami peningkatan dari 3,63\% menjadi 22,15\%. Demikian pula Ciptaan dan Mirnawati, (2001) melaporkan bahwa pada kulit pisang batu kandungan protein kasar meningkat $54,02 \%$ yaitu $9,2 \%$ tanpa difermentasi menjadi $14,17 \%$ setelah difermentasi dengan Rhizopus oligosporus.

\section{KESIMPULAN}

Berdasarkan hasil penelitian ini dapat disimpulkan bahwa biokonversi kulit pisang raja (Musa paradisiaca) dengan Rhizopus oligosporusdapat meningkatkan persentase perubahan kandungan bahan kering dan protein kasar tetapi terjadi penurunan kandungan bahan organik. Penggunaan dosis inokulum 0,4\% dan waktu fermentasi 96 jam (P5) dapat meningkatkan persentase perubahan kandungan bahan kering sebesar 6,55\%, menurunkan persentase perubahan bahan organik sebesar 3,97\% dan meningkatkan persentase perubahan protein kasar sebesar $60,91 \%$.

\section{DAFTAR PUSTAKA}

Abun. 2003. Biokonversi Ampas UmbiGarut (Maranta arundina LINN.) oleh Aspergillus niger Terhadap Perubahan Komposisi Gizi dan Nilai Energi Metabolis Pada Ayam Broiler. Tesis. Universitas Padjajaran.Bandung.

Ciptaan G. dan Mirnawati, 2001.BeratOrgan Fisiologis Ayam Broilerpada Ransum yang Memakai Kulit Pisang Batu(Musa brachiarpa) Fermentasi. Jurnal Andalas 13: 8-13.

Fardiaz, S. 1992. Mikrobiologi Pangan 1 Gramedia Pustaka Utama,Jakarta.

Kasmiran. A. 2011. Pengaruh Lama Fermentasi Jerami Padi dengan Mikroorganisme Lokal Terhadap Kandungan Bahan Kering, Bahan Organik dan Abu. Jurnal Lentera. $11: 48$-52

Koni.TNI.2013. Pengaruh Pemanfaatan Kulit Pisang Yang Difermentasi Terhadap Karkas Broiler. JITV $18: 153-157$.

Matsir. M. H., dan I. H. Djunaidi. 2016.Pengaruh

Fermentasi 
Terhadap Kandungan Zat Makanan Campuran Limbah Garut dan Limbah Udang. Jurnal Ilmu Ilmu Hayati. 18: 88-96

Mirzah dan H. Muis. 2015. Peningkatan Kualitas Nutrisi Limbah Ubi Kayu Melaluib Fermentasi Menggunakan Bacillusamylo liquefaciens. JPI. Vol.17 : 131-142

Setiyatwan, H. 2007. Peningkatan Kualitas Nutrisi Duckweed Melalui Fermentasi Menggunakan trichoderma harzianum. JIT. 7: 113-116.

Steel, C. J. dan J. H. Torrie. 1995. Prinsip dan Prosedur Statistik. PT. Gramedia. Jakarta.

Winarno, S. J. 1980 Fundamental of Fung. Second Edition. Prentice Hall. New Jersey.

Yohanista, M., O. Sofjan, E. Widodo. 2014. Evaluasi Nutrisi Campuran Onggokdan Ampas Tahu Terfermentasi Aspergillus niger, Rhizopus oligosporus dan Kombinasi Sebagai Bahan Pakan Pengganti Tepung Jagung. JIIP. $24: 72-83$. 